International Journal of Environment, Agriculture and Biotechnology
Vol-6, Issue-3; May-Jun, 2021
J Journal Home Page Available: https://ijeab.com/
Journal DOI: $10.22161 /$ ijeab

Article

Peer-Reviewed Journal

\title{
Utilization of E-learning by Agricultural Students of Public Higher Institutions in Southwest of Nigeria
}

\author{
Sola Joshua Oluwasusi ${ }^{1}$, Oluwatoyin Olagunju ${ }^{2 *}$, Adeyose Emmanuel Akinbola ${ }^{3}$, Oyedeji \\ Taofeeq Yekinni ${ }^{4}$
}

\author{
1,4 Department of Agricultural Extension and Rural Development, University of Ibadan, Ibadan, Nigeria \\ ${ }^{2}$ Department of Agricultural Extension and Rural Development, Adekunle Ajasin University, Akungba-Akoko, Nigeria \\ ${ }^{3}$ Department of Agricultural Economics, Adekunle Ajasin University, Akungba-Akoko, Nigeria \\ *Corresponding Author
}

Received: 13 May 2021; Received in revised form: 11 Jun 2021; Accepted: 21 Jun 2021; Available online: 29 Jun 2021

(C)2021 The Author(s). Published by Infogain Publication. This is an open access article under the CC BY license

(https://creativecommons.org/licenses/by/4.0/).

\begin{abstract}
This study aimed at determining the utilization of e-learning by agricultural students' of public higher institutions in the Southwest of Nigeria. A multistage sampling procedure was used to select 300 respondents from the higher institutions. Students were mostly female with a mean age of 22.4 years and with majority enrolled in undergraduate programmes. Respondents had a low usage of e-learning due to low awareness and knowledge level, complexity of technology and inadequate e-learning infrastructures in their schools. A significant relationship existed between constraints, awareness, knowledge, and utilization of e-learning. The regression analysis carried out in this study resulted in $R$-square of .957. These findings indicate that about $95.7 \%$ of variance in the level of usage of $e$ learning is explained by awareness, knowledge and different constraints. The study recommends that efforts should be geared towards encouraging students to integrate e-learning usage in their academic activities by providing elearning infrastructures and easy access through competent e-learning personnel.
\end{abstract}

Keywords-Agricultural students, E-Learning, Higher institution, Utilization

\section{INTRODUCTION}

Technology has inevitably become the most powerful tool in almost every aspect of human's daily life as is regarded as the precursor of major revolutions in various aspects of human endeavours, including education (Lee et al., 2018). The use of Information Technology (IT) is the new paradigm of learning in the 21 st century that allows people to easily access, gather data, analyse and transfer of knowledge (Darling-Hammond et al., 2020). This makes it possible to function as teachers, study mates and more importantly, as tools to improve the entire teaching and learning process. This current development which relates to the role of IT and the Internet shows that the phase of the whole educational system has changed. Information and communication technologies (ICTs) hold immense capability to gradually transform and remould education (Assar, 2015). The ultimate impact of ICTs may be seen on the structure, content and outcomes of learning, both inside and outside of school. Bader and Kottstorfer (2013) reported trends in technology influence on education and knowledge management and that E-learning is gradually becoming important in higher institutions of learning by providing E-learning resources through allowing profile registrations on the internet by more students.

E-learning is an aspect and/or manifestation of e-readiness, which is the general term for using computer and other electronic technologies to promote teaching and learning that may include the use of the technologies as part of the conventional or traditional teaching where learners and teachers may never meet face to face (Khvilon \& Patru, 2018; Lakshmi et al., 2020). The technology includes not just computers and networks that connect them but also software such as email, online databases, CD-ROMs and the peripherals such as video cameras and interactive white 
boards (Anderson, 2010). E-learning is also the use of ICT to promote the acquisition of more efficient and effective learning materials and results, facilitate the accessibility of research findings and educative write-ups, allow greater students' access to information and make researchers more accountable to students and the general public (Eze et al., 2018). The concept of e-learning has brought about changes in knowledge management and human resources development (Subramanian, 2016). Increasing capacity of ICT has further been empowered by the growth of a global network of computer networks known as internet (Teng et al., 2020). It has impacted in the way business is conducted, facilitated learning and knowledge sharing, generated global information flows, empowered citizens and communities in ways that have re-defined governance and have created significant wealth and economic growth resulting in a global information society (Cascio \& Montealegre, 2016).

Agricultural education in tertiary institutions is one of the ways of preparing for sustainable agricultural development through the training of farmers and allied professionals as well as agricultural extension practitioners (Kozicka, 2018). Agricultural education implies training people in a way to be futuristic in their exploitation of nature with adequate consideration for the environmental, societal and economic factors in a balanced way, in the pursuit of development and improved quality of life (Smith \& Rayfield, 2016). Many of today's major challenges include; energy security, national security, human health, and climate change that are closely tied to the global food and agriculture enterprise (Islam \& Kieu, 2020). Academic institutions with programmes in agriculture are in a perfect position to foster the next generation of leaders and professionals needed to address these challenges (Ikehi et al., 2014). However, to keep pace with changing times, undergraduate agricultural education needs a new focus. Agriculture is affected by so many factors and its participants must always be prepared to react, adapt, and think ahead (Alawa et al., 2014).

Tertiary institutions with undergraduate programmes in agriculture must undergo a significant transformation to foster the agricultural workforce of tomorrow. Such institutions must position themselves at the cutting-edge and offer students the opportunity to learn about the complexities of agriculture, grapple with its emerging challenges, and find their opportunity to contribute as leaders and participants (Carlisle et al., 2019). Keeping up with the evolving nature of the agricultural enterprise is not a simple task. It requires a much more dynamic approach to the curriculum and teaching methods than most academic institutions have developed (Njura et al., 2020).
Increased awareness of agriculture's important role in addressing major societal problems can help to raise the profile of the field and attract more students (FAO, 2014). Transforming and sustaining education in agriculture requires an ongoing commitment with strong leadership and interest in agriculture (Ameyaw et al., 2019). The investments in undergraduate education will play an important role in shaping the future of agriculture in meeting the challenges of the $21^{\text {st }}$ century and beyond. In achieving sustainable agriculture, e-learning is one of the ways to improving Agricultural education in the world ( $\mathrm{Ra}$ et al., 2019).

According to Apuke and Iyendo (2018), the educational sector is yet to tap into this technology to deliver services especially in our tertiary institutions due to high cost of internet access and lack of reliable and permanent sources of power, causing loss of interest from students who believed in e-learning as a good way of impacting knowledge on them. Poor telecommunication penetration hinders access to e-learning facilities in many towns and cities in the country and also, the cost of owing personal computers is a major hurdle for the most of the Nigerian students (Atanda, 2014).

ICTs hold great potential for supporting and augmenting existing education as well as national development efforts (Idowu \& Esere, 2013). The functionality of ICTs in agricultural education delivery is faced with enormous challenges in the nation's higher institutions, among which include inadequate ICT infrastructure, including high cost of band width access, lack of skilled manpower, to manage available systems and inadequate training facilities for ICT education at the tertiary level (Yushau \& Nannim, 2018). Moreover, resistance to change from traditional pedagogical methods to innovative, technology based teaching and learning methods from students and academic staff is yet an important issue (Howard \& Mozejko, 2015). The overall educational system is grossly under-funded and therefore, available funds are used to solve more seemingly urgent and basic needs by the institutions (Adeniran et al., 2019). In addition, the overdependence of educational institutions on government has limited tertiary institutions ability to collaborate with the private sector or seek alternative funding sources for ICT educational initiatives and more so, ineffective coordination of various ICT for educational initiatives, give room to mushroom education across the nation's educational institutions (Gana, 2017). These challenges throw many tertiary institutions to operate beyond capacity.

Addressing the agricultural students' usage of e-learning in tertiary institutions across the country is paramount, in order to gauge progress and pro-actively address stumbling blocks. It is important to conduct a study on the utilization 
of e-learning among agricultural students as it is crucial for the country's participation in the information society and a promising effective strategy academic performance and agricultural transformation in the country. Thus, this study aimed at examining the utilization of e-learning by agricultural students of public higher institutions in Southwest of Nigeria. Specifically, the objectives to be achieved are as follows:

1. describe the personal characteristics of agricultural students;

2. determine the level of awareness of e-learning facilities available to agricultural students;

3. examine the knowledge level of the agricultural students on the use of e-learning;

4. determine the level of usage of e-learning by agricultural students;

5. identify constraints to the use of e-learning by agricultural students.

\subsection{Hypotheses of the study}

1. $\mathrm{H}_{\mathrm{o}}$ : There is no significant relationship between personal characteristics of agricultural students and their usage of e-learning.

2. $\mathrm{H}_{\mathrm{o}}$ : There is no significant relationship between agricultural students' levels of awareness, knowledge, constraints and their level of usage of e-learning.

\section{MATERIAL AND METHODS}

\subsection{Study area}

The study was carried out in Southwest zone of Nigeria. Southwest lies between latitude $6030^{\prime} \mathrm{N}$ to $9^{\prime} \mathrm{N}$ and longitude $300^{\prime} \mathrm{E}$ to $5030^{\prime} \mathrm{E}$. It is majorly a Yoruba speaking area, although there are different dialects even within the same state. The weather conditions vary between the two distinct seasons in Nigeria; the rainy season (March-November) and the dry season (NovemberFebruary). The dry season also brings Harmattan dust and cold dry winds from the northern deserts blow into the southern regions around this time.

\subsection{Study population}

The research population comprises of all agricultural student in public tertiary institutions in Southwestern Nigeria.

\subsection{Sampling procedure and sample size}

Multistage sampling procedure was used to select students for the study. The first stage involved the simple random selection of three out of the six states in the zone; the selected states are Osun, Ondo and Ekiti. The second stage involved the stratification of the institutions in the selected states into University, Polytechnic and College of education. Osun State had two Universities, two Polytechnic and two Colleges of Education; Ondo State had four Universities, two Polytechnics and one College of Education, while Ekiti State had two Universities, one College of Education and one Polytechnic. In the third stage simple random sampling was adopted to select $50 \%$ of the selected Universities, Polytechnics and Colleges of Education in the selected States respectively. Hence, three, four and three institutions were selected in Osun State (one University, one Polytechnic and one College of Education; Ondo State (two Universities, one Polytechnic and one College of Education and Ekiti State (one University, one Polytechnic and one College of Education) respectively. The fourth stage involved simple random selection of one department in the Faculty of Agriculture in the selected institutions. The fifth stage involved simple random selection of (a quota) thirty (30) students using the final year list of 2018/2019 from the selected Departments of the sampled fifteen tertiary institutions, which gave a sample size of 300 respondents.

\subsection{Data collection and analysis}

Data collection was conducted using structured questionnaire. The information was gathered by using an interview schedule made up of well-structured open and close-ended questions. To test the stated hypotheses, the data were analyzed using descriptive and inferential statistics like Pearson Product Moment Correlation (PPMC) and Regression analysis. The personal characteristics of the respondents were presented using frequency counts, percentages and means.

\section{RESULTS AND DISCUSSION}

\subsection{Personal characteristics of the respondents}

The findings presented in Table 1 shows that more than half $(55.3 \%)$ of the respondents were female, while $44.7 \%$ of them were male. This implies that the females were more involved in agricultural education in the study area. Obayelu \& Fadele (2019) supported this finding that across tertiary institutions, the ratio of female to male respondents studying Agricultural Science is most times skewed towards the females emphasizing that they are more willing to study agriculture in tertiary institution than their male counterparts.

The mean age of the students was 22.4 , with more than half $(63.3 \%)$ of them falls between 20 and 25 years of age. This implies that they were young and very active in learning by having a high tendency of learning innovations in various e-learning facilities. This makes it easy for them 
to change from analogue age to the digital age and the departure philosophy to do something new will not be frustrating (Eze et al., 2018).

Likewise, the findings showed that $70.3 \%$ students are Christians, while $29.3 \%$ are Muslims and only $0.3 \%$ practice traditional religion. Hence, students of the selected public higher institutions are predominantly Christians. This is manifested in the existence of churches in the areas. This shows that education is accepted by the two prevailing religions. The implication is that there is no religious taboo against the acquisition of tertiary education in the study area. Majority $(92.0 \%)$ of the respondents were single while $8.0 \%$ of the respondents were married. This indicates that the single people could get more focused, boost their capacity to seek, utilize information and become excellent in their academic pursuits than the married people as they are limited to little family responsibilities (Moses et al., 2020).

On the category of students programme, majority $(82.0 \%)$ were undergraduate students, $11.0 \%$ were preliminary students, while $7.0 \%$ of them were postgraduate students. This implies that undergraduate programme is the foundation and mainstay of tertiary education in the study area with the attraction of lesser fees compared to post graduate study which is an afterthought degree, carried out by fewer respondents because it requires more money, dedication and vast knowledge of ICT application to pursue satisfactorily.

Table 1 further revealed $53.3 \%$ of students were University students, $26.7 \%$ were in the Polytechnic and $20.0 \%$ were Colleges of Education students. This implies that many students were studying agriculture in the university compared to other higher institutions because university education is more popular, recognized and better professionalized than other tertiary education in the study area. This result is consistent with the study of Yang et al. (2015) and Chankseliani et al. (2021); they validated that Universities play major roles not only in national but also, increasingly in regional economic development in the delivery of life-long learning and development of civic culture.

Also, as revealed on Table 1, 87.6\% of the respondents were between 100 and 500 levels, while few of them were between 600 and 800 levels (Postgraduate). This implies that the higher the students grow in academics, the tougher the agricultural programmes become. Fewer students survive it to higher levels and could only pursue higher studies in agricultural based courses through the University alone.
Table 1 Personal characteristics of the respondents $(n=300)$

\begin{tabular}{|c|c|c|c|c|}
\hline \multirow{2}{*}{$\begin{array}{l}\text { Variable } \\
\text { Gender }\end{array}$} & \multirow{2}{*}{$\begin{array}{c}\text { Category } \\
\text { Male }\end{array}$} & \multirow{2}{*}{$\begin{array}{c}\text { Freq. } \\
134\end{array}$} & \multicolumn{2}{|c|}{ Percentage } \\
\hline & & & 44.7 & \\
\hline & Female & 166 & 55.3 & \\
\hline & $14-19$ & 60 & 20 & \\
\hline \multirow[t]{5}{*}{ Age } & $20-25$ & 190 & 63.3 & Mean \\
\hline & $26-31$ & 48 & 16 & Age $=$ \\
\hline & $32-37$ & 1 & 0.3 & 22.4 \\
\hline & $38-43$ & 1 & 0.3 & \\
\hline & Christianity & 211 & 70.3 & \\
\hline \multirow[t]{2}{*}{ Religion } & Islam & 88 & 29.3 & \\
\hline & Traditional & 1 & 0.3 & \\
\hline \multirow{2}{*}{$\begin{array}{l}\text { Marital } \\
\text { status }\end{array}$} & Married & 24 & 8.0 & \\
\hline & Single & 276 & 92.0 & \\
\hline \multirow{3}{*}{$\begin{array}{l}\text { Category of } \\
\text { student } \\
\text { programme }\end{array}$} & Preliminary & 33 & 11.0 & \\
\hline & Undergraduate & 246 & 82.0 & \\
\hline & Postgraduate & 21 & 7.0 & \\
\hline \multirow{3}{*}{$\begin{array}{l}\text { Type of } \\
\text { institution }\end{array}$} & University & 160 & 53.3 & \\
\hline & Polytechnic & 80 & 26.7 & \\
\hline & College of Education & 60 & 20.0 & \\
\hline \multirow{2}{*}{$\begin{array}{l}\text { Level of } \\
\text { programme }\end{array}$} & $1-5$ & 263 & 87.6 & \\
\hline & $6-8$ & 37 & 12.3 & \\
\hline \multirow{9}{*}{$\begin{array}{l}\text { Monthly } \\
\text { stipend per } \\
\text { semester }(\#)\end{array}$} & $<\$ 10000(\$ 21)$ & 104 & 34.7 & \\
\hline & $\begin{array}{c}\$ 10001-20000(\$ 21- \\
42)\end{array}$ & 108 & 35.9 & $\begin{array}{l}\text { Mean } \\
\text { Income }\end{array}$ \\
\hline & $\begin{array}{c}\$ 20001-30000(\$ 42- \\
63)\end{array}$ & 39 & 13.0 & $\begin{array}{l}= \\
20109\end{array}$ \\
\hline & $\begin{array}{l}\$ 30001-40000(\$ 63- \\
83)\end{array}$ & 16 & 5.3 & \\
\hline & $\begin{array}{c}\$ 40001-50000(\$ 83- \\
104)\end{array}$ & 12 & 3.9 & \\
\hline & $\begin{array}{l}\$ 50001-60000 \\
(\$ 105-125)\end{array}$ & 13 & 4.3 & \\
\hline & $\begin{array}{l}¥ 60001-70000 \\
(\$ 126-145)\end{array}$ & 4 & 1.3 & \\
\hline & $\begin{array}{l}\text { (\$146-167) } \\
\quad \$ 10001-80000\end{array}$ & 2 & 0.6 & \\
\hline & $\begin{array}{c}\$ 80001(\$ 168) \text { and } \\
\text { Above }\end{array}$ & 2 & 0.7 & \\
\hline
\end{tabular}

Table 1 further shows the mean income of students per semester was $\$ 20,109$ (\$42). The majority (70.6\%) of them earn between $\$ 10,000$ (\$21) and $\$ 20,000$ (\$42) as monthly stipends per semester, while the remain students (29.1\%) earn above $\$ 20,000$ (\$42) as monthly stipends per 
semester. This indicated that almost all the respondents earn lesser income as monthly stipends from parents, guardians or self-labour to cope effectively with their academic demands and that could negatively affect their information seeking and utilization behaviour to e-learning facilities. This finding was consistent with Okoro (2021) as she confirmed that inadequate funding is the major constraints of using e-learning facilities during teaching and learning process.

\subsection{Level of awareness of e-learning facilities available to agricultural students}

In accordance with the rating of low and high, as indication of level of awareness of available e-learning facilities, the respondents' scores in level of awareness as shown in Table 2, range 1-22 with a mean of 10.9. To find the level of awareness of available e-learning facilities, the scores were grouped into two categories; low (0-11) and high (12-22). The analysis revealed that level of awareness of available e-learning facilities by the respondents, with a majority $(71.0 \%)$ claiming to be as low, while $29.0 \%$ indicated that the level of awareness of available elearning facilities is high. The result shows that the respondents' low level of awareness was due to inadequate provision of the needed e-learning facilities on campuses by various institutions which will not be the best way for students to be aware of new technology, willing and interested to study in various concepts in searching and upgrading their knowledge (Suresh et al., 2018).

Table 2 Distribution of respondents' on level of awareness of available e-learning facilities

\begin{tabular}{lcc}
\hline Level of awareness & Frequency & $\begin{array}{c}\text { Percentage } \\
(\boldsymbol{\%})\end{array}$ \\
\hline Low $(0-11)$ & 213 & 71.0 \\
High $(12-22)$ & 87 & 29.0 \\
\hline Total & 300 & 100.0 \\
\hline
\end{tabular}

\subsection{Knowledge level of the agricultural students on the use of e-learning}

As shown in Table 3, the students' scores of knowledge level on the use of e-learning range from (1-14) with a mean score of 5.4. To determine the level, the respondents' scores were grouped into two categories. It described (0-7) as low, and (8-14) as high. The results of the level of knowledge according to the respondents', with more than half $(53.0 \%)$ stating as low, while $47.0 \%$ of the total respondents indicated high level of knowledge towards the use of e-learning facilities. The implication is that many of the respondents did not have good knowledge of the use of e-learning facilities and this might hinder their readiness for the usage and invariably lead to the experience of low readiness for e-learning. Eze et al. (2018) validated this finding by attributing some of the reasons for low elearning adoption in higher institutions ranges from lack of specialized and social aptitudes required for the execution of e-learning and teachers to lack of teachers and students knowledge and the know-how to use e-learning platforms.

Table 3 Distribution of respondents' on level of knowledge on the use of e-learning

\begin{tabular}{lcc}
\hline $\begin{array}{l}\text { Level of } \\
\text { knowledge }\end{array}$ & Frequency & Percentage (\%) \\
\hline Low (0-7) & 159 & 53.0 \\
High (8-14) & 141 & 47.0 \\
\hline Total & 300 & 100.0 \\
\hline
\end{tabular}

\subsection{Level of usage of e-learning facilities by agricultural students}

The respondents' score in Table 4 reveals the mean is 8.8 . To determine the level of usage of e-learning, the respondents' scores were grouped into two categories. It described (0-9) as low, and (10-18) as high. The results on the usage of e-learning facilities indicated that more than half $(56.0 \%)$ stating as low. While $44.0 \%$ of the total respondents indicated high level on the usage of e-learning facilities which implies that the extent at which the students use e-learning facilities are still very low and this can be as result of not being knowledgeable enough about the usage. In line with this, Almaiah et al. (2020) found that academic staff knowledge of learning technologies, student knowledge and technical infrastructure, were significant factors in facilitating the successful acceptance and usage of e-learning in universities.

Table 4 Distribution of respondents' on level of usage of elearning facilities

\begin{tabular}{lcc}
\hline Level of usage & Frequency & Percentage (\%) \\
\hline Low $(0-9)$ & 168 & 56.0 \\
High $(10-18)$ & 132 & 44.0 \\
\hline Total & 300 & 100.0 \\
\hline
\end{tabular}

3.5. Constraints encountered in the use of elearning facilities by agricultural students

Table 2 shows the distribution of respondents by weighted scores in which poor electricity supply (WS=148.3), complexity of technology (WS=131.1), insufficiency of financial resources for technology integration (WS=128.7) and inadequate e-learning infrastructures in my school (WS $=128.3$ ) as a serious constraints to the use of e- 
learning facilities. While inadequate access to e-learning facilities (WS=118.9), poor ICT literacy (WS=109.9), lack of interest of teachers and students (WS=109.3) indicate mild constraints to the used of e-learning. This indicates that irregular supply of electricity, lack of fund to integrate the technology, inadequate infrastructure and complexity of the technology serves as serious constraints towards the use of e-learning facilities in public higher institutions in Nigeria. The result of the study corroborate the assertion of Eze et al. (2020) that decrease in the annual budget for the education sector and current electricity supply in Nigeria is very low, unstable and not available in many part of the country where most of the higher institutions of learning are located.

\section{Table 5 Distribution of respondents according to constraints to use of e-learning}

\begin{tabular}{|c|c|c|c|c|}
\hline Constraints & $\begin{array}{l}\text { Serio } \\
\text { us } \\
\text { const } \\
\text { raint }\end{array}$ & $\begin{array}{l}\text { Mild } \\
\text { constr } \\
\text { aint }\end{array}$ & $\begin{array}{c}\text { Not } \\
\text { a } \\
\text { cons } \\
\text { train } \\
t\end{array}$ & $\begin{array}{l}\text { Weig } \\
\text { hted } \\
\text { Score }\end{array}$ \\
\hline $\begin{array}{l}\text { Poor electricity and } \\
\text { power supply }\end{array}$ & 60.0 & 28.3 & 11.7 & 148.3 \\
\hline $\begin{array}{l}\text { Complexity of } \\
\text { Technology }\end{array}$ & 50.7 & 29.7 & 19.7 & 131.1 \\
\hline $\begin{array}{l}\text { Insufficiency of } \\
\text { financial resources for } \\
\text { technology integration }\end{array}$ & 43.7 & 41.3 & 15.0 & 128.7 \\
\hline $\begin{array}{l}\text { Inadequate e-learning } \\
\text { infrastructures in my } \\
\text { school }\end{array}$ & 46.3 & 35.7 & 18.0 & 128.3 \\
\hline $\begin{array}{l}\text { Inadequate access to } \\
\text { e-learning facilities }\end{array}$ & 38.3 & 42.3 & 19.3 & 118.9 \\
\hline $\begin{array}{l}\text { Inefficiency of } \\
\text { guidance and support } \\
\text { by administration }\end{array}$ & 38.3 & 38.3 & 23.3 & 114.8 \\
\hline $\begin{array}{l}\text { Lack of relevance of } \\
\text { courses to e-learning } \\
\text { offered to students }\end{array}$ & 37.7 & 36.3 & 26.0 & 111.7 \\
\hline $\begin{array}{l}\text { Incompetent e- } \\
\text { learning personnel to } \\
\text { put me through }\end{array}$ & 39.7 & 31.7 & 28.7 & 111.1 \\
\hline Poor ICT literacy & 36.3 & 37.3 & 26.3 & 109.9 \\
\hline $\begin{array}{l}\text { Lack of interest of } \\
\text { teachers and students } \\
\text { in IT usage }\end{array}$ & 36.0 & 37.3 & 26.7 & 109.3 \\
\hline
\end{tabular}

\subsection{Hypotheses testing}

The result obtained in Table 6 clearly reveals that there had been no significant relationship between selected personal characteristics of the students; gender $(t=0.857$, $\mathrm{p}>0.05)$, age $(\mathrm{t}=-0.007, \mathrm{p}>0.05)$, category of student programme $(\mathrm{t}=1.136, \mathrm{p}>0.05)$, level of programme $(\mathrm{t}=$ $1.600, \mathrm{p}>0.05)$, monthly stipend per semester $(\mathrm{t}=0.609$, $\mathrm{p}>0.05)$ and their usage of e-learning. This result implies that the students' usage of e-learning is irrespective of their personal characteristics but on their level of awareness and knowledge to the use of e-learning. In a related study, Fleming et al. (2017) and Bączek et al. (2021) reiterated that age, gender and level of study are not a significant factor impacting the use of e-learning among the students.

Furthermore, the result from Table 6 shows that a significant relationship existed between students' levels of awareness $(t=14.672, \mathrm{p}<0.05)$, knowledge $(\mathrm{t}=31.903$, $\mathrm{p}<0.05)$, constraints $(\mathrm{t}=2.555, \mathrm{p}<0.05)$ and the level of elearning usage. The predicted relationship has been established; meaning that for student to use e-learning facilities effectively, their level of awareness and knowledge need to be increased as well as reduce certain constraints to its usage such as poor electricity and power supply which serves as a serious constraint in the study (Oyediran et al., 2020). This result might stem from the fact that the students were not previously exposed to elearning facilities due to inadequate awareness and knowledge (Olayemi et al., 2021). Similarly, result obtained by Ngampornchai and Adams (2016) on students' acceptance and readiness for e-learning in Northeastern Thailand and Nigeria. They revealed the reason why usages of e-learning were low among students was as a result of low awareness and knowledge level, complexity of technology and inadequate e-learning infrastructures in the school. Almaiah et al. (2020) also reported similar results that lack of awareness and knowledge lead to students not taken responsibility for their e-learning utilization.

The regression analysis carried out in this study resulted in R-square of .957 . These findings indicate that about $95.7 \%$ of variance in the level of usage of e-learning is explained by awareness, knowledge and constraints. The significant variables are shown in Table 6 below. Since the $p$ value is less than 0.05 , it indicates that there is a significant relationship between level of awareness, knowledge, constraints and utilization of e-learning. 
Table 6 Determinants of the use of e-learning among agricultural students

\begin{tabular}{lccc}
\hline Variables & Coefficient & $\begin{array}{c}\text { t- } \\
\text { value }\end{array}$ & Significance \\
\hline Constant & \multicolumn{2}{c}{0.000} \\
Gender & 0.011 & 0.857 & 0.857 \\
Age & -0.007 & -0.007 & -0.404 \\
Category of & 0.018 & 1.136 & 0.257 \\
$\begin{array}{l}\text { Student } \\
\text { Programme }\end{array}$ & & & \\
$\begin{array}{l}\text { Level of } \\
\text { Programme }\end{array}$ & -0.030 & -1.600 & 0.111 \\
$\begin{array}{l}\text { Monthly Stipend } \\
\text { Per Semester }\end{array}$ & 0.008 & 0.609 & 0.543 \\
$\begin{array}{l}\text { Awareness of e- } \\
\text { learning }\end{array}$ & 0.221 & 14.672 & 0.000 \\
$\begin{array}{l}\text { Knowledge of e- } \\
\text { learning }\end{array}$ & 0.411 & 31.903 & 0.000 \\
$\begin{array}{l}\text { Constraints to the } \\
\text { use of e-learning }\end{array}$ & 0.333 & 2.555 & 0.011 \\
\hline
\end{tabular}

$\mathrm{R}=0.978$, R-square $=0.957$, Adjusted R-square $=0.955$, $\mathrm{df}=11, \mathrm{~F}=577.761$

\section{CONCLUSION}

The study investigated the e-learning utilization among agricultural students in public higher institutions in Southwest of Nigeria. It can be concluded that there is low utilization of e-learning in the study area. The study found significant association between constraints faced by students in the utilization of e-learning, students' awareness of the use and knowledge of e-learning. The major constraints affecting respondents' utilization of elearning include poor electricity and power supply, complexity of technology, insufficiency of financial resources for technology integration, and inadequate elearning infrastructures in their various higher institutions.

\section{RECOMMENDATIONS}

Based on the findings of the study, it is recommended that:

1. Tertiary institutions should concentrate on sustainable and internal power generation through usage of solar panel or independent power projects by converting dams in schools where they have them to power generation centres. This could be achieved by sensitizing and lobbying the public through mass media on the importance of stable electric supply for concrete and quality research to attain good and reliable policy formulations for government to accede to this lofty demand.

2. Higher Institutions should enhance institutional rewards for high quality teaching and research development among lecturers.

3. Adequate attention should be given to up-to-date and make e-learning facilities accessible in public higher institutions, to broaden the horizon of agricultural students on relevant information and exchange of ideas that will change their knowledge, skills and attitudes to proper and good usage of e-learning facilities for effective learning.

4. Agricultural students should be more encouraged to integrate e-learning usage in their daily academic and non-academic endeavours in order to internalize and get more acquainted to its usage every time.

5. e-learning facilities should be made more available, accessible and affordable to students with less bureaucracy so that students would enjoy a more viable, robust, reliable, efficient, effective and cost beneficial educational acquisition.

6. Tertiary Institutions should increase student opportunities to participate in the outreach and extension activities during the farm practical training year programmes.

7. Staff and students of the university need to be well informed about the content and provisions in available ICT policies as a means of making all stakeholders adequately informed.

8. There is need for higher institutions to seek private sector collaboration as alternative means of funding ICT and e-learning educational initiatives, as it availability in schools is pertinent for effective teaching and learning.

\section{REFERENCES}

[1] Adeniran, A., Onyekwena, C., Onubedo, G., Ishaku, J., \& Ekeruche, A. (2019). Is Nigeria on track to achieving quality education for all? Drivers and implications.

[2] Alawa, D. A., Asogwa, V. C. \& Ikelusi, C. O. (2014). "Measures for mitigating the effects of climate change on crop production in Nigeria." American Journal of Climate Change, 2014(3), 161-168.

[3] Almaiah, M. A., Al-Khasawneh, A., \& Althunibat, A. (2020). Exploring the critical challenges and factors influencing the E-learning system usage during COVID-19 pandemic. Education and Information Technologies, 25, 5261-5280. 
[4] Ameyaw, J., Turnhout, E., Arts, B., \& Wals, A. (2019). Creating a responsive curriculum for postgraduates: lessons from a case in Ghana. Journal of Further and Higher Education, 43(4), 573-588.

[5] Anderson, J. (2010). ICT transforming education: A regional guide. Published by UNESKO Bangkok, 120.

[6] Apuke, O. D., \& Iyendo, T. O. (2018). University students' usage of the internet resources for research and learning: forms of access and perceptions of utility. Heliyon, 4(12), e01052.

[7] Assar, S. (2015). Information and Communications Technology (ICT) and Education. International Encyclopedia of the Social \& Behavioral Sciences, Elsevier, pp.66 - 71, 2015, 978-0-08-0970875.10.1016/B978-0-08-097086-8.92104-4. hal02386986

[8] Atanda, B. N. (2014). Issues of e-learning in developing countries: a Nigerian perspective. In The 5th International Conference on Information and Communication Technology for the Muslim World (ICT4M) (pp. 1-4). IEEE.

[9] Bączek, M., Zagańczyk-Bączek, M., Szpringer, M., Jaroszyński, A., \& Wożakowska-Kapłon, B. (2021). Students' perception of online learning during the COVID-19 pandemic: a survey study of Polish medical students. Medicine, 100(7), 1-6.

[10] Bader, L., \& Köttstorfer, M. (2013). E-learning from a student's view with focus on Global Studies. Multicultural Education \& Technology Journal, 7(2/3), 176-191.

[11] Carlisle, L., De Wit, M. M., DeLonge, M. S., Calo, A., Getz, C., Ory, J., ... \& Iles, A. (2019). Securing the future of US agriculture: the case for investing in new entry sustainable farmers. Elementa: Science of the Anthropocene, 7(17), 1-20.

[12] Cascio, W. F., \& Montealegre, R. (2016). How technology is changing work and organizations. Annual Review of Organizational Psychology and Organizational Behavior, 2016(3), 349-375.

[13] Chankseliani, M., Qoraboyev, I., \& Gimranova, D. (2021). Higher education contributing to local, national, and global development: new empirical and conceptual insights. Higher Education, 81(1), 109127.

[14] Darling-Hammond, L., Flook, L., Cook-Harvey, C., Barron, B., \& Osher, D. (2020). Implications for educational practice of the science of learning and development. Applied Developmental Science, 24(2), 97-140.
[15] Eze, S. C., Chinedu-Eze, V. C., \& Bello, A. O. (2018). The utilisation of e-learning facilities in the educational delivery system of Nigeria: a study of MUniversity. International Journal of Educational Technology in Higher Education, 15(1), 1-20.

[16] Eze, S. C., Chinedu-Eze, V. C., Okike, C. K., \& Bello, A. O. (2020). Factors influencing the use of elearning facilities by students in a private Higher Education Institution (HEI) in a developing economy. Humanities and Social Sciences Communications, 7(1), 1-15.

[17] Fleming, J., Becker, K., \& Newton, C. (2017). Factors for successful e-learning: does age matter?. Education+ Training, 59(1), 76-89.

[18] Food and Agricultural Organization of the United Nations (FAO). (2014). Youth and agriculture: Key challenges and concrete solutions.

[19] Gana, E. (2017). Innovative Approaches to Teaching and Learning of Christian Religious Studies in Nigerian Tertiary Institutions: A Case Study of Ahmadu Bello University, Zaria, Nigeria. International Journal Of Education, 2(2), 166-180.

[20] Howard, S. K., \& Mozejko, A. (2015). Teachers: technology, change and resistance. Teaching and digital technologies: Big issues and critical questions, 307-317.

[21] Idowu, A. I., \& Esere, M. (2013). ICT and higher educational system in Nigeria. Educational Research and Reviews, 8(21), 2021-2025.

[22] Ikehi, M. E., Ifeanyieze, F. O. \& Ugwuoke, C. U. (2014). Integration of Climate Change into the Senior Secondary School Agricultural Science Curriculum in Nigeria. Atmospheric and Climate Sciences, 2014(4), 614-621.

[23] Islam, M. S., \& Kieu, E. (2020). Tackling Regional Climate Change Impacts and Food Security Issues: A Critical Analysis across ASEAN, PIF and SAARC. Sustainability, 12(3), 1-21.

[24] Khvilon, E., \& Patru, M. (2018). Information and communication technologies in teacher education: A planning guide.

[25] Kozicka, O. K. (2018). Vocational Education and Training for Farmers and Other Actors in the AgriFood Value Chain in Africa. Bonn: Center for Development Research, University of Bonn.

[26] Lakshmi, Y. V., Das, J., \& Majid, I. (2020). Assessment of e-Learning Readiness of Academic Staff \& Students of Higher Education Institutions in 
Gujarat, India. Indian Journal of Educational Technology, 2(1), 31-45.

[27] Lee, M. H, Yun, J. J., Pyka, A., Won, D., Kodama, F., Schiuma, G., Park, H., Jeon, J., Park, K., Jung, K., Yan, M. R., Lee, S., \& Zhao X. (2018). How to respond to the fourth industrial revolution, or the second information technology revolution? Dynamic new combinations between technology, market, and society through open innovation. Journal of Open Innovation: Technology, Market, and Complexity, 4(21), 1-24.

[28] Moses, J. B., Akporehwe, N. J., \& Agah, R. (2020). Effect of Electronic-Learning on the Academic Achievement of Basic Science Students in Bayelsa State, Nigeria. African Research Review, 14(1), 210216.

[29] Ngampornchai, A., \& Adams, J. (2016). Students' acceptance and readiness for E-learning in Northeastern Thailand. International Journal of Educational Technology in Higher Education, 13(1), $1-13$.

[30] Njura, H. J., Kaberia, I. K., \& Taaliu, S. T. (2020). Effect of agricultural teaching approaches on skills development for food security: a case of secondary schools in Embu County, Kenya. The Journal of Agricultural Education and Extension, 26(3), 239252.

[31] Obayelu, O. A., \& Fadele, I. O. (2019). Choosing a career path in Agriculture: A tough calling for youths in Ibadan metropolis, Nigeria. Agricultura Tropica Et SubTropica, 52(1), 27-37.

[32] Okoro, P. E. (2021). Constraints and Prospects of ELearning in Universities as Perceived by Business Education Lecturers in South-South Nigeria. Library Philosophy and Practice, 1-15.

[33] Olayemi, O. M., Adamu, H., \& Olayemi, K. J. (2021). Perception and Readiness of Students' Towards Online Learning in Nigeria During Covid-19 Pandemic. Perception, 3, 4-2021.

[34] Oyediran, W. O., Omoare, A. M., Owoyemi, M. A., Adejobi, A. O., \& Fasasi, R. B. (2020). Prospects and limitations of e-learning application in private tertiary institutions amidst COVID-19 lockdown in Nigeria. Heliyon, 6(11), e05457.

[35] Ra, S., Ahmed, M., \& Teng, P. S. (2019). Creating high-tech 'agropreneurs' through education and skills development. International Journal of Training Research, 17(sup1), 41-53.
[36] Smith, K. L., \& Rayfield, J. (2016). An Early Historical Examination of the Educational Intent of Supervised Agricultural Experiences (SAEs) and Project-Based Learning in Agricultural Education. Journal of Agricultural Education, 57(2), 146-160.

[37] Subramanian, R. M. (2016) "The role of e-learning, the advantages and disadvantages of its adoption in Higher Education, Tamilnadu, 2(12), 397-410.

[38] Suresh, M., Vishnu Priya, V., \& Gayathri, R. (2018). Effect of e-learning on academic performance of undergraduate students. Drug Invention Today, 10(9), 1797-1800.

[39] Teng, M. F., Putra, Y. K., Ilham, M., \& Pratama, W. A. Y. (2020). How much does distance learning affect social life and psychology of growing adolescent? Bulletin of Social Informatics Theory and Application, 4(2), 52-58.

[40] Yang, J., Schneller, C., \& Roche, S. (Eds.). (2015). The role of higher education in promoting lifelong learning. Hamburg: UNESCO Institute for Lifelong Learning.

[41] Yushau, B., \& Nannim, F. A. (2018). ICT facilities and their utilization for educational purposes in Nigerian universities: A review of literatures from 2004 to 2018. ATBU Journal of Science, Technology and Education, 6(1), 237-263. 